\title{
ヒ卜抗体の開発と応用はざこまで進んでいるか ゼノマウスの開発とその周辺
}

\section{松本 隆志*}

1975 年のモノクローナル抗体作製法の確立以来, 病気の治 療に利用できるヒト抗体作製の試みが続けられてきた。弚の 間, 抗体の多様性の仕組みが解明されるなど, 免疫系のメカ ニズムに対する理解も急速に深まってきた。一方で，発生エ 学と呼ばれる個体の形質の改変技術も大きな進歩をとげ, 現 在では任意の遺伝子をマウス個体で発現させたり, あるいは マウスの内在遺伝子を欠損させたりすることが可能になって いる. こうした技術の進歩によって, これまで抗体の利用面 で大きな障害となっていた免疫原性の問題, これを解決する ための完全ヒト抗体作製法の問題に, 今確かな答えが出され ようとしている.

ほとんどの抗原は複数のエピトープをもっている.そ のため, 生体内ではそれぞれのエピトープと特異的に結 合する様々な抗体分子が生産される.これら抗体の混合 物をポリクローナル抗体と呼ぶが, これに対して, 同一 抗体の集団をモノクローナル抗体と呼ぶ。モノクローナ ル抗体を得るためには，特定の抗原エピトープで刺激を 受けた B 細胞を単離してコロニーを作り, 分泌抗体を 集めなければならない.ところが, $\mathrm{B}$ 細胞を試験管内で

*Takashi MATSUMOTO, 日本たばこ産業(株)医薬探索研究所 What is Going on for the Production and the Use of Fully Human Antibodies?
長期間培養することはきわめて難しい. 一方, 癌細胞は 長期間培養が可能である。たとえば，HeLa 細胞株は 1940 年代後半に樹立され，今日まで維持されている.

1975 年, ジョージ・ケラーとセザール・ミルシュタイ ンは, マウス骨髄腫細胞と B 細胞を融合することによ り，B 細胞の不死化集団ができることを発見し，モノク ローナル抗体の作製法を完成した。この融合細胞をハイ ブリドーマと呼ぶ. 単一のハイブリドーマは増殖し, コ ロニーを形成することができる．しかもこれらの細胞が つくる抗体はすべて同一である(1).

モノクローナル抗体は, 高い抗原特異性と親和性をも ち, しかも安定供給が可能なことから, 病気の治療や診 断に応用しようとする研究が始まった. 1980 年代にな つて, 癌の診断, 治療, 免疫応答の調節, 自己免疫疾患や 臓器移植拒絶といった臨床への応用が検討された。特に 抗体が癌の治療にとって強力な武器になるのではないか と大きな期待がかけられ，“魔法の弾丸（Magic Bullets)”と呼ばれたときもあった。しかし，結果は期待に 添うものではなく，予想したほど治療効果が上がらず， 抗体のもつ潜在的な可能性を十分に引き出すまでにはい たらなかった ${ }^{(2)}$. 今日まで世界で実用化されている治療 用モノクローナル抗体は，4品目にとどまっている. 
しかし，1990 年代初めからの遺伝子操作，タンパク 質工学, トランスジェニック動物の作製などの技術進歩 は著しく, 最近になってヒ卜抗体そのものの作製が可 能になり，再び治療用抗体の新展開が期待できるように なってきた．本稿では特に，日本たばこ産業（JT）と Abgenix 社が共同開発したヒト抗体を作るトランスジ エニックマウスとその周辺について解説する.

\section{免疫原性の低減に向けて}

病気の治療に抗体を利用しようとするとき，最も大き な障害はその抗体タンパク質のもつ免疫原性である。す なわち，治療用抗体そのものが，ヒトの免疫系において は抗原として認識される可能性が高い，最近までの治療 用抗体は，まだ何らかの形でマウス由来のアミノ酸配列 をもっていた，ヒトの免疫系は，これらマウス由来の配 列を異種として容易に同定してしまう。そのため，治 療用抗体に対する抗体が直ちにできる。こうしてできた ヒ卜抗マウス抗体 (human antimouse antibodies; HAMA) は，抗体の治療効果を減少させてしまう。さら に，その治療をさらに繰り返したりすると，患者は致命 的なアナフィラキシーショックの危険にさらされること になる．また，血液中で抗体と HAMA の結合物が沈殿 し，これが特に肝臓や腎臟に対して毒性を示すことにも なる.

外来タンパク質は，生体内では専門化した抗原提示細 胞によって取り込まれた後，そのタンパク質はぺプチド に分解され，主要組織適合遺伝子複合体 (MHC) クラス II 分子に結合する。これが細胞表面に発現してへルパー $\mathrm{T}$ 細胞に提示される。これによって活性化されたへル パー T 細胞は, B 細胞の増殖と抗体を分泌する形質細 胞への分化を誘導する，抗原提示細胞は，凝集した抗原
や粒子状の抗原を好んで摂取する．抗原タンパク質が大 きく複雑なほど，あるいは自己タンパク質との関連性が 少ないほど，その抗原は MHC 分子に結合するぺプチ ドを多くもち，自己のぺプチドとの識別が容易にな $3^{(3)}$.

免疫原性に結びつくタンパク質の性質としては，(1)分 子の大きさ，(2)構造，(3)コンフォメーション，(4)分解 性，(5)外来性などがある．分子の大きさは，2,500 Da より小さくなると免疫原とはなりにくく，数百 $\mathrm{kDa} の$ 大きさであれば効果的な免疫原となる．また，構造の複 雑さも兔疫原性に結びつく. 多くの多糖類でみられるよ うな繰り返し構造は，一般的に免疫原にはなりにくい. 効果的な免疫応答は，大きな外来タンパク質分子の小ペ プチド分子への分解性にも依存している，たとえばDアミノ酸からなっている合成タンパク質のように，分解 できない分子は免疫原として作用しない。

これらの視点からながめると, 非ヒト抗体は最も免疫 原性を高める特徵をもっているということができる。す なわち，抗体分子の大きさは $150 \sim 900 \mathrm{kDa}$ と大きく， 構造も複雑で安定なコンフォメーションをもっている. プロテアーゼで分解され，しかもヒトと異なる組成をも ったタンパク質である。これらの特徴の中で, 構造の複 雑さ，安定なコンフォメーション，プロテアーゼによる 分解などは，種が異なっていてもいずれの抗体タンパク 質ももつ, タンパク質本来の特徵である.したがって, 免疫原性を減少させるためには，分子の大きさをいかに 小さくするか，外来性をいかに少なくするか，すなわち 自己タンパク質との類似性をいかにして上げるかという ことになる。

\section{1. 抗体の小分子化}

抗原の免疫原性を減少させる方法の一つは, 抗体の構

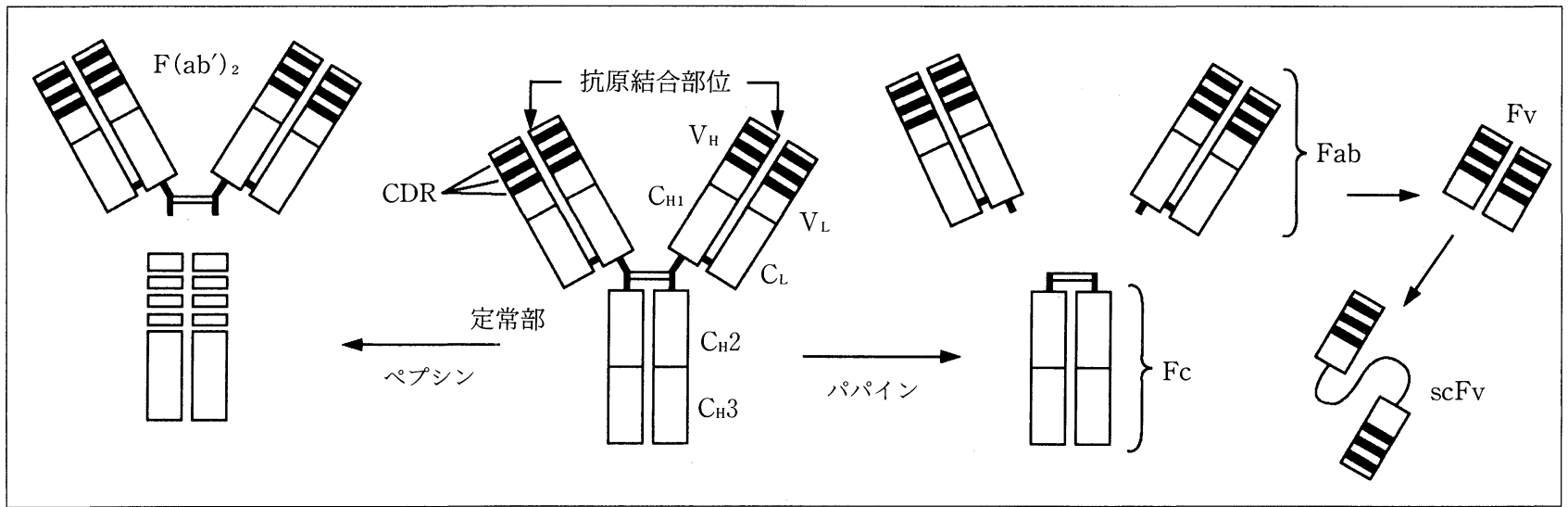

図 1 -抗体の構造と抗体の小分子化 
造から不必要な部分を除き，小分子化することである (図 1). 抗体分子をパパインで部分的に消化すると，抗 原と結合することのできる Fab フラグメントと，抗原 とは結合できない Fc フラグメントを分離できる．また ペプシンで切断すると, 分解する場所が異なるため, 一 対の $\mathrm{Fab}$ フラグメントが結合した形の $\mathrm{F}\left(\mathrm{ab}^{\prime}\right)_{2}$ フラグ メントが得られる。これらのフラグメントをさらに小さ くし，抗体の抗原結合部位のみにすることもできる。こ の場合は，正しいコンフォメーションを維持できるよう に， $\mathrm{V}_{\mathrm{H}}$ ドメインと $\mathrm{V}_{\mathrm{L}}$ ドメインを結合し一本鎖にする 必要がある。これを single chain Fv ( $\mathrm{scFv})$ と呼ぶ.

結合には，抗体のヒンジ部分に存在する S-S 結合, あるいは 2 つタンパク質ドメインを安定化できる適当 なリンカー分子が必要である。こうしたことで免疫原性 を減少させることができる. しかし，これら小分子化し たフラグメントには，抗体の Fc 領域に存在する補体活 性化部位やマクロファージ結合部位がない。そのため, 抗原抗体反応に続いて起こるエフェクター機能と呼ばれ る免疫系の働きを，治療効果を上げるために利用できな いことになる。一方，フラグメントが小さくなればなる ほど，拡散能が増し，組織の隅々にまで浸透し，抗原に 到達しやすくなり分解も速くなる。これは, 血液中での 速いクリアランス，標的部位への集積のしやすさにつな がり，抗体によるターゲティングにとって都合のよい特 徵でもある.

\section{2. 抗体のキメラ化とヒト化}

抗体の外来性を少なくし，ヒトタンパク質との類似性 を増すために，多くの努力が積み重ねられてきた。たと えば治療用抗体を作るために，マウスの抗体を構成する アミノ酸配列をできるだけヒトのアミノ酸配列に近づけ ようとして種々の方法が考案された。

1980 年代半ば，まずマウスモノクローナル抗体を八 イブリドーマ法で作り，それをマウス抗体を基本にして ヒト型に近づける技術が開発された。つまり，抗原の結 合に必須でないマウス抗体のパーツを，遺伝子組換えに より相当するヒトのパーツに置き換えるというものであ る.これをキメラ化 (chimeric) とヒト化(humanized) という.

\section{a） キメラ抗体(図 2)}

マウス抗体の V 領域とヒト抗体の $\mathrm{C}$ 領域を遺伝子組 換えにより結合し，キメラ抗体を作製する，マウス抗体 のもつ抗原特異性, 親和性, 結合力を損なわずに, ヒト タンパク質との類似性を増し, 免疫原性を減少させよう とするものである．初期の治療用抗体はこのタイプが多

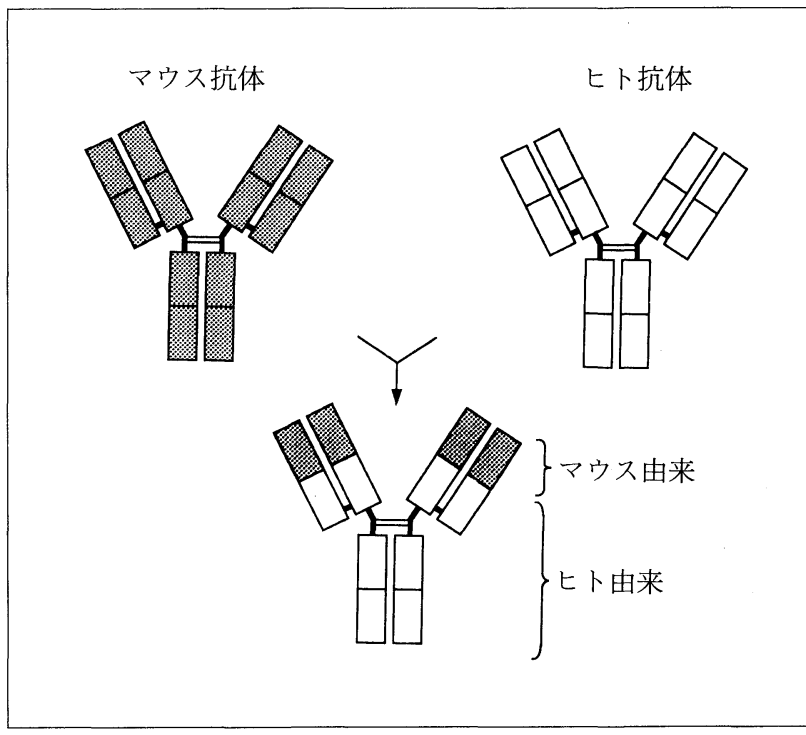

図 2 ・キメラ抗体

く，ヒト抗体由来のアミノ酸配列は約 $70 \%$ あった。 キメラ抗体の免疫原性は減少したとはいえ，まだ無視で きない HAMA 反応を示す ${ }^{(4)}$.

\section{b) ヒト化抗体(図 3)}

抗体 $\mathrm{V}$ 領域は，抗体間で比較的保存されたアミノ酸 配列をもつフレームワーク $(\mathrm{FW})$ と，抗原の結合に直接 関与し，抗原エピトープごとに異なるアミノ酸配列を示 す，相補性決定部 (CDR) からなっている，FW は，ジ スルフィド結合で結ばれた，逆平行 $\beta$ シート構造をと っている. CDR は，外側に向いたループ構造をとり， 抗体分子の表面を形成している．H 鎖および $\mathrm{L}$ 鎖でそ れぞれ 3 個所， 6 個の CDR が，抗原との結合に直接関 与している.

1986 年遺伝子組換えにより，マウスのモノクローナ ル抗体から抗原との結合に必須の CDRのみを残し, $\mathrm{FW}$ と $\mathrm{C}$ 領域をヒト抗体由来のアミノ酸配列とした, ヒト化抗体の作製が報告された。この技術は CDR グラ フティングとも呼ばれている。

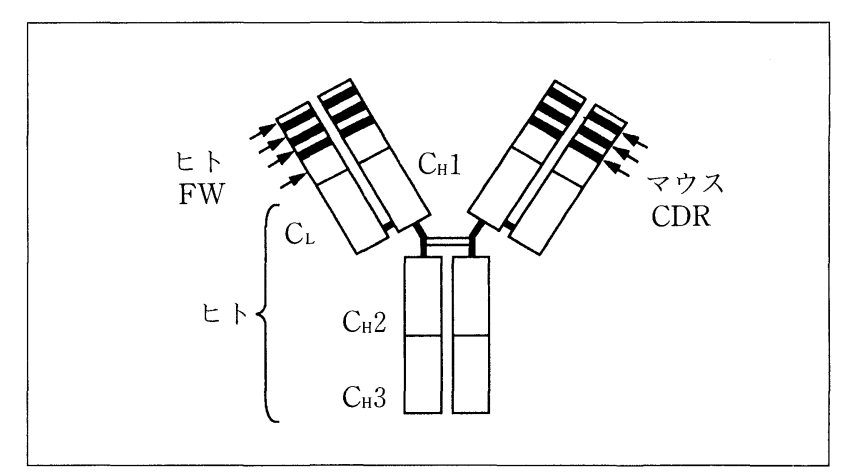

図 3 -ヒト化抗体 
キメラ抗体では，抗原特異性，親和性に変化はなかっ たのに対し，この技術が開発された当初は，抗体の CDR を単純に置き換えるだけでは，十分な抗原との結 合特異性や親和性を示す抗体を得ることはできなかっ た。そのため, CDR 特有のコンフォメーションを維持 するには, FW 配列の一部が必要なのではないかと考え られた。そこで，FW の置換でひき起こされる， CDR のコンフォメーションのゆがみの問題を解決するため に, 合理的分子設計技術が駆使された。その結果, CDRの正しいコンフォメーションを維持するには, $\mathrm{FW}$ 中の数個のアミノ酸が必要であることが明らかにな

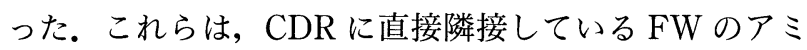
ノ酸配列であることがわかった。

CDR グラフティングでは, 抗原特異性, 親和性を損 なわないために，マウス CDR だけではなく，こうした マウスアミノ酸配列が保存されている。したがって，七 卜化抗体では，ヒト抗体由来のアミノ酸配列は，約 90 \%程度にとどまる，ヒト化抗体の臨床試験が進むにつれ て，ヒト化抗体の免疫原性に関する知見が蓄積されてい くであろうが, 現在のところ, 単回投与でも抗イディオ タイプ抗体の出現があると報告されている. 反復投与, 長期連続投与では, 免疫原性が問題となる可能性は残っ ている(5).

ヒト化キメラ抗体のマウス由来のアミノ酸配列は，七 トの免疫系にとって，すべてが等しく免疫原性がある わけではない，免疫応答の多くは，抗体表面に存在する わずかのマウスアミノ酸配列が引き金になる。このこと から，抗体表面のアミノ酸配列のみを七ト化（resurfaced）すればよいのではないかということで, これら の配列を，構造的に似ている免疫原性のないヒトの配列 に置き換え, 抗体の全体構造への変化を極力抑え, 抗原 との結合特性にほとんど変化を与えない方法も開発され つつある。

\section{ヒト抗体光のものの作製}

異種抗体による免疫原性の問題を解決する最も簡単な 答は, 異種抗体ではなく, ヒト抗体そのものを用いるこ とである. 1990 年代の初めから, 完全ヒト抗体 (fully human mAbs）の作製をめざして，2つの技術開発が 別々に始まった。一つはトランスジェニックマウスによ る方法であり，もう一つはファージディスプレーによる 方法である(6).

1980 年代の初め頃, 発生工学の進歩により, 動物胚 に外来の遺伝子を導入し, そのまま発生を続けさせ個体
の形質を変えるトランスジェニック技術が可能になっ た. 80 年代半ばには, 全能性を保った胚性幹細胞（ES 細胞）が樹立され，この細胞を胚盤胞腔内に注入するこ とによって, ES 細胞由来の子孫が得られることが示さ れた。また，遺伝子の相同組換え (homologous recombination）の発見と効率的な濃縮法を含む応用技術の確 立により, 特定の遺伝子に突然変異を導入する方法, ジ ーンターゲティング技術が生み出された ${ }^{(7)}$. こうした技 術の進歩の扔かげで, マウスの免疫グロブリン遺伝子 を，ヒトの免疫グロブリン遺伝子とそっくり入れ換えた マウスが完成した，つまり，相同組換えにより，マウス の免疫グロブリン遺伝子をターゲティングし, 酵母の人 工染色体 (YAC) を用いて, ヒトの免疫グロブリン遺伝 子をマウスゲノムに挿入したマウスである ${ }^{(8)}$.

このマウスの子孫は, マウス免疫グロブリンの代わり にヒト免疫グロブリンを作る．このマウスをゼノマウス (XenoMouse $^{\mathrm{TM}}$ ) II と呼んでいる。ゼノマウスIIは，も とのマウスと同様に二次免疫応答を起こすことができ, 治療用抗体として最も適している高い特異性と親和性を もつ IgGクラスのヒト抗体を産生することができる. このゼノマウスに免疫原を投与すれば，あとはすでに一 般化しているマウスモノクローナル抗体の作製手順に従 って，完全ヒトモノクローナル抗体を作ることができ る. 正常なヒトの免疫系においては, ヒトの組織に結合 するヒト抗体は産生されない.ところが, ゼノマウスの 免疫系は, ヒト由来の免疫原でも外来タンパク質と認識 して，ヒト抗体産生のための遺伝子転写のスイッチをオ ンにすることができる.

\section{1. ゼノマウス II の作製}

完全ヒトモノクローナル抗体作製のストラテジーは, マウスの免疫グロブリン遺伝子座をヒトの相当する遺伝 子座に置き換え, マウスの体液性免疫系を “ヒト化”す ることである.つまり，マウスのもつ免疫系の多様化・ 選択の仕組みをそのまま利用しょうとするものである。

抗体分子の多様性は, いくつかの異なったメカニズム によって生み出される. その一つは, 抗体の抗原結合部 である可変部の $\mathrm{H}$ 鎖, L 鎖をコードする, 多数の遺伝 子断片の存在によって生じる. ヒトの $\mathrm{H}$ 鎖と $\varkappa \mathrm{L}$ 鎖 $(\mathrm{L}$

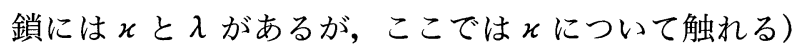
の遺伝子座は, 14 番染色体と 2 番染色体上に, それぞ れ 150 万塩基対以上の大きさで存在している. $\mathrm{H}$ 鎖遗 伝子座には, $\mathrm{V}_{\mathrm{H}}$ 遺伝子断片として現在明らかなもの約 95 種類, $\mathrm{D}$ 遺伝子断片として約 30 種類, $\mathrm{J}_{\mathrm{H}}$ 遺伝子断 片として 6 種類, おょび C 領域 $\left(\mu, \delta, \gamma_{3}, \gamma_{1}, \psi_{1}\right.$, 
$\left.\alpha_{1}, \psi_{2}, \gamma_{2}, \gamma_{4}, \varepsilon, \alpha_{2}\right)$ の遺伝子断片が存在している. $\varkappa \mathrm{L}$ 鎖遺伝子座は, $\mathrm{V}_{\kappa}$ 遺伝子断片として 76 種類, $\mathrm{J}_{\kappa}$ 遺 伝子断片として 5 種類, さらに $\mathrm{C}_{\kappa}$ 遺伝子断片からなっ ている. $\mathrm{H}$ 鎖遺伝子は, 最初に D と $\mathrm{J}_{\mathrm{H}}$ の間で再編成が 起こり, 続いて $\mathrm{D}-\mathrm{J}_{\mathrm{H}}$ 遺伝子ドメインと $\mathrm{V}_{\mathrm{H}}$ 間で再編成 が起こる. D の存在のためにより大きなバリエーショ ンが可能となっている， $x \mathrm{~L}$ 鎖遺伝子は， $\mathrm{V}_{\kappa}$ と $\mathrm{J}_{\kappa}$ 間の 再編成後, 結合してできた $\mathrm{V}_{\kappa}-\mathrm{J}_{\kappa}$ 遺伝子ドメインに $\mathrm{C}_{\kappa}$ が結合してできる．抗体レパートリーは，これらのごく 限られた数の抗体遺伝子と, その再編成によって生じる 多様性の拡大によって生み出される.

したがって，ヒトの抗体レパートリーを確立するため には, 数百万塩基対にも及ぶ, ヒト免疫グロブリン遺伝 子座が必要となる。これをどのようにしてクローニング し, マウスの生殖細胞系列に移行させるかは, ゼノマウ ス作製にとって大きな課題であった。

一方，マウスにヒトの免疫グロブリン遺伝子座をうま く導入できたとしても，マウスの免疫グロブリン遺伝子 が正常に機能していれば，元のマウス遺伝子の発現が優 先的に起こると考えられる。つまり，ヒト抗体産生シス

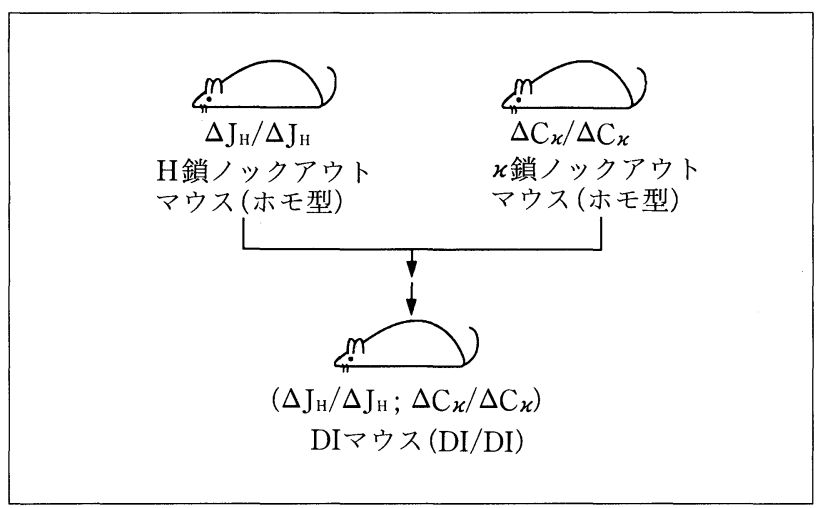

図 4 ・マウス免疫グロブリン遺伝子を不活性化したマウス の作製
テムとして動かすためには, マウス抗体の産生を止める 必要がある，そのため，マウス $\mathrm{H}$ 鎖の遺伝子再編成に 必要な $\mathrm{D}$ と $\mathrm{J}_{\mathrm{H}}$ 遺伝子領域を選び， $\mathrm{D}$ 領域の一部とす べての $\mathrm{J}_{\mathrm{H}}$ 領域をターゲティングしたマウスを作った. これを， $\varkappa \mathrm{L}$ 鎖遺伝子の $\mathrm{C}_{\kappa}$ をターゲティングしたマウ スと交配して，マウス免疫グロブリン遺伝子を不活性化 したマウス，すなわちマウス抗体レパートリーをもたな いマウス（double inactivated mouse；DI マウス）を 作ることができた(図 4).この DI マウスでは，B細胞 の分化は初期の状態でとどまっており， $\operatorname{IgM}$ の産生は まったく行なわれていない.

初期の研究では, 数個の $\mathrm{V}$ 遺伝子断片をもつミニ遺 伝子座を, YAC または別の方法でDI マウスに導入し てヒト抗体産生を調べている。この場合には，生殖細胞 型のヒト遺伝子はわずか $200 \mathrm{~kb}$ ほどで， $\mathrm{V}_{\mathrm{H}}$ 遺伝子断片 としては 4〜5 種類, $\mathrm{V}_{\kappa}$ 遺伝子断片としては 3〜 4 種類, さらに $\mathrm{D}, \mathrm{J}, \mathrm{C}$ 領域の遺伝子断片が入っている。この ように V 遺伝子断片の数が限られたものであっても, 不活性化したマウス免疫グロブリン遺伝子座に代わって 組換えを起こし，完全なヒト抗体としてマウス B 細胞 で発現することが確認されている ${ }^{(6,9)}$.このことは，近 接した正常な数の $\mathrm{D}, \mathrm{J}$ 遺伝子を含んでいれば， $\mathrm{V}$ 遺伝 子の数が限られていても機能することを示している.し かし再構築された部分は小さく，できたマウスは実用的 なものではなかった。成熟 $\mathrm{B}$ 細胞の数だけでなく，血 中免疫グロブリンのレベルも低く，限られた数の抗原に 対してしかヒトモノクローナル抗体は作れなかった。

マウスにおける体液性免疫の再現が不完全なのは，抗 体の多様性を決定している可変部の遺伝子，すなわち $\mathrm{V}$ 遺伝子のレパートリーが少ないためである。そのた め, ヒト免疫グロブリン遺伝子の YACライブラリーの スクリーニングを精力的に繰り返し，巨大な領域をカバ

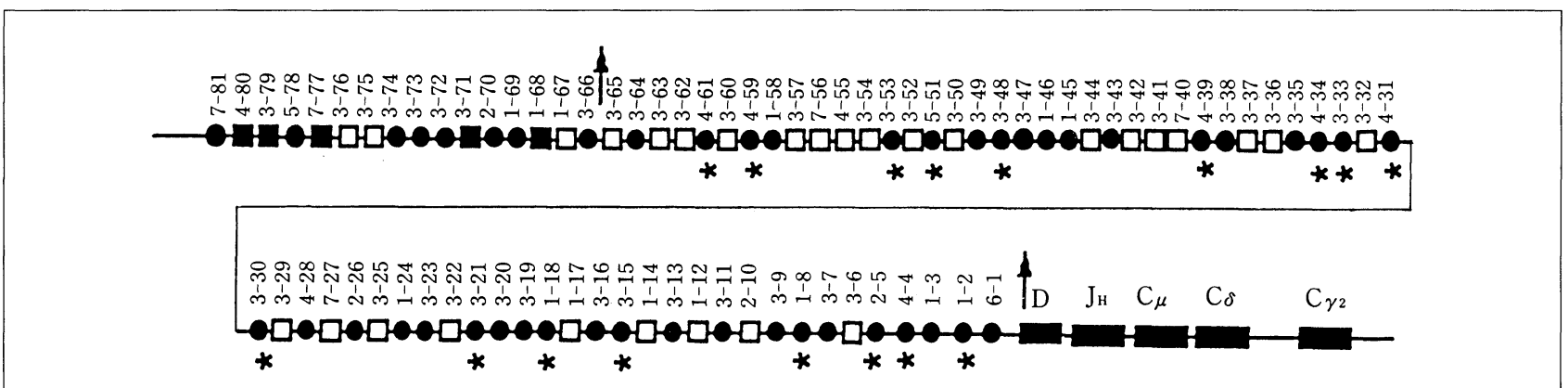

図 5 ・ゼノマウス II に導入したヒト H 鎖遺伝子の構造

ゼノマウス IIに導入したヒト $\mathrm{H}$ 鎖遺伝子（ $\mathrm{yH} ）$ は，約 $1,000 \mathrm{~kb}$ の大きさの生殖細胞型遺伝子で， $\mathrm{V}_{\mathrm{H}}$ 遺伝子領域は， $\uparrow$ で示した $66 \mathrm{~V}_{\mathrm{H}}$ 遺 伝子断片，完全な $\mathrm{D}$ 領域と $\mathrm{J}_{\mathrm{H}}$ 領域，および 3 つの異なる定常部遺伝子 $\left(\mu, \delta, \gamma_{2}\right)$ を含んでいる. ○：翻訳領域， $\square ：$ 偽遺伝子。： * こ れまでにゼノマウスIIから得られたヒト抗体で使われていた V 遺伝子 


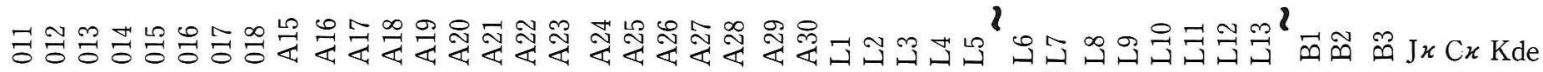

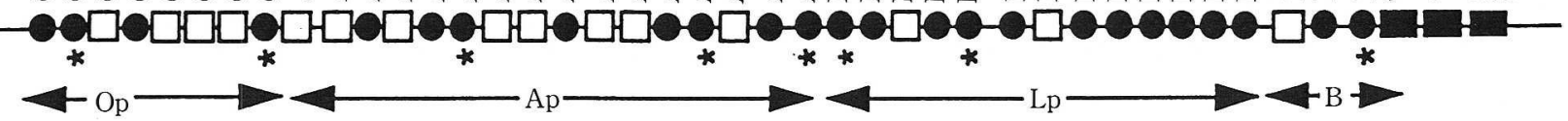

図 6 ロゼノマウス II に導入したヒト $x \mathrm{~L}$ 鎖遺伝子の構造

ゼノマウス II に導入したヒト $x \mathrm{~L}$ 鎖遺伝子 $\left(\mathrm{y} \varkappa\right.$ ）は，800 kb の大きさの生殖細胞型遺伝子で， $\mathrm{V}_{x}$ 遺伝子領域は 32 の遺伝子断片（ ( で示さ れた $\mathrm{Lp}$ 領域の一部は欠失)，完全な $\mathrm{J}_{k}$ 領域，および 1 つの定常部遺伝子 $\left(\mathrm{C}_{k}\right)$ を含んている。：翻訳領域， $\square$ ：偽遺伝子。*：これま でにゼノマウスIIから得られたヒト抗体で使われていた V 遺伝子

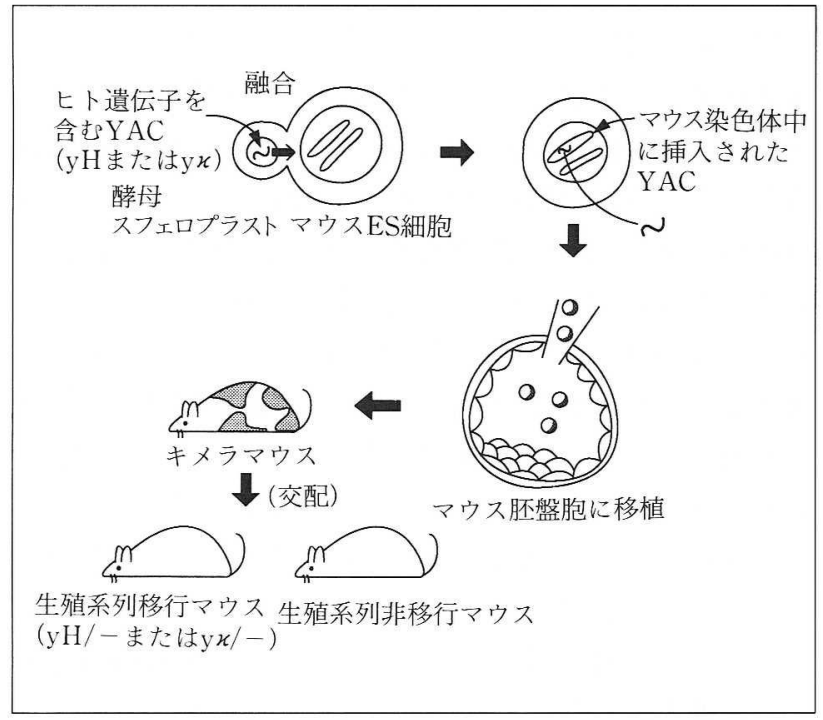

図 7 ロヒト免疫グロブリン遺伝子を導入したマウスの作製
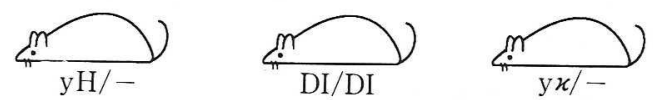

ヒトH鎖導入マウス (へテロ型)

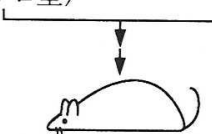

$(\mathrm{yH} /-; \mathrm{DI} / \mathrm{DI})$

ウス(ホモ型) ヒトル鎖導入マウス (へテロ型)

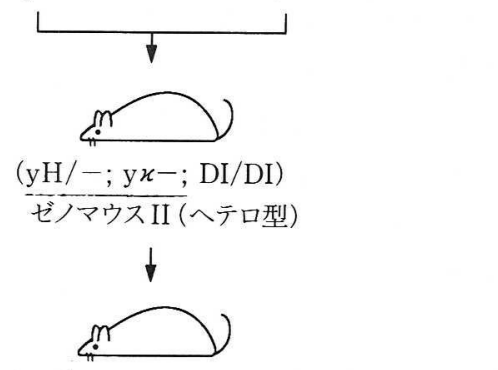

$(\mathrm{yH} / \mathrm{yH} ; \mathrm{y} \varkappa / \mathrm{y} \varkappa ; \mathrm{DI} / \mathrm{DI})$

ゼノマウスII (ホモ型)

図 8 ・ゼノマウス II の作製

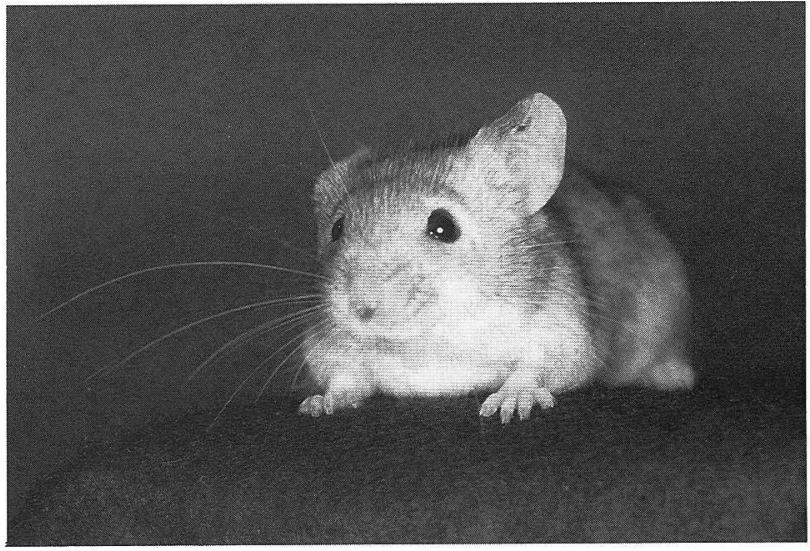

図 9日ヒト抗体を作るゼノマウス II

外見は普通のマウスと変わらない.

ーできるYACクローンを集めた。これらを相同組換え でつなぎ合わせ，巨大遺伝子を再構築した(図 5，図 6)。 YAC 上に再構築したヒト $\mathrm{H}$ 鎖遺伝子座には，66 種類 の $\mathrm{V}_{\mathrm{H}}$ 遺伝子断片，完全な $\mathrm{D}$ 領域， $\mathrm{J}_{\mathrm{H}}$ 領域，さらに C 領域 $\left(\mu, \delta, \gamma_{2}\right)$ の遺伝子断片が存在する.大きさは $1,020 \mathrm{~kb}$ にも及ぶ。 YAC 上に再構築したヒト $x \mathrm{~L}$ 鎖遺 伝子座には, 32 種類の $\mathrm{V}_{\kappa}$ 遺伝子断片, 完全な $\mathrm{J}_{\kappa}$ 領域, さらに $\mathrm{C}_{\kappa}$ 遺伝子断片が存在し，大きさは約 $800 \mathrm{~kb}$ にな る。これら生殖細胞型遺伝子配列のヒト $\mathrm{H}$ 鎖，ヒ卜 $\varkappa \mathrm{L}$ 鎖遺伝子座を含む巨大 $\mathrm{YAC}$ を，それぞれ $\mathrm{ES}$ 細胞 に導入し，キメラを経て，生殖系列に移行したマウスを 得た(図 7)。 YACの ES 細胞への導入は，YACを含む 酵母スフェロプラストと， $\mathrm{ES}$ 細胞を融合することによ って行なった。融合細胞 2 千万個に 1 個の割合で, YAC が入った $\mathrm{ES}$ 細胞を拾うことができた。

このようにしてできたヒト免疫グロブリントランスジ エニックマウスと，マウス免疫グロブリン不活性化マウ ス（DI マウス）を交配して生まれたのが，ゼノマウス II である(図8, 図 9)。これは，七ト $\mathrm{H}$ 鎖とヒト $\varkappa \mathrm{L}$ 鎖 $\mathrm{YAC} を ち ， マ ウ ス の \mathrm{H}$ 鎖と $\varkappa \mathrm{L}$ 鎖が不活性化されて いる. 


\section{2. ゼノマウス II の性質}

巨大なヒト免疫グロブリン遺伝子座をマウスに導入す ることにより，ヒト抗体生産システムをマウスで再現す ることができた。ゼノマウスIIの体液性免疫応答は，ど のようになっているのだろうか.

\section{a) 成熟 B 細胞のレベル}

DI マウスでは，B細胞の分化はほとんど進んでいな い.しかしゼノマウスIIでは，普通のマウスに近い正常 な B 細胞の分化が起こっている．すべての B 細胞では， ヒトIgMを発現しており，そのうち約 $60 \%$ がヒト $\mathrm{IgD}$ 分子を細胞表面上に発現している成熟 B 細胞であ る。これは，七ト免疫グロブリン遺伝子の再編成と，V 遺伝子レパートリーの形成によって，B 細胞の分化が進 んだためと考えられる. IgM と IgD を発現している成 熟 $\mathrm{B}$ 細胞は, 骨髄を離れ, リンパ組織を経由して, 抗 原に遭遇するまで生体内を循環している。

\section{b) アイソタイプスイッチ}

成熟 B 細胞は抗原と遭遇すると, $\mathrm{H}$ 鎖の VDJ 遺伝 子ドメインと, その $3^{\prime}$ 側にクラスターを形成して存在 している定常部遺伝子 $\left(\mathrm{C}_{\mathrm{H}}\right)$ の再編成が誘導され, ある 一つの抗体クラス（アイソタイプ）を分泌するように運 命づけられる。ゼノマウス II の血清中の IgM, IgGの レベルは普通のマウスの值と近く, IgM から IgGへの アイソタイプスイッチは効率よく行なわれていると考え られる。

\section{c）ヒト抗体応答の多様性}

ゼノマウスIIで発現しているヒト抗体遺伝子のレパー トリー解析では, 導入したヒト $\mathrm{V}_{\mathrm{H}}, \mathrm{D}, \mathrm{J}_{\mathrm{H}}$ 遺伝子断片 の使用頻度は，ヒトでみられるパターンとよく似てい る。これらの $\mathrm{V}_{\mathrm{H}}-\mathrm{D}-\mathrm{J}_{\mathrm{H}}$ は，ヒト $\mu$ または $\gamma_{2}$ と結合し ており, $\mathrm{V}_{\mathrm{H}}-\mathrm{D}-\mathrm{J}_{\mathrm{H}}$ 再編成の際に, 結合部で起こる $\mathrm{N}$ 又 クレオチド付加もみられる，最も多様性に富む CDR 3 の長さは 8〜19アミノ酸からなっており，ヒトとよく似 ている， $\varkappa \mathrm{L}$ 鎖でも，ヒト $\mathrm{V}_{\kappa}, \mathrm{J}_{\kappa}$ 遺伝子断片の使用頻 度は，ヒトでみられるパターンと類似している， $\mathrm{V}_{\kappa}-\mathrm{J}_{\kappa}$ は， $C_{k}$ と正しく結合しており, $\operatorname{CDR} 3$ の長さは 9 10 アミノ酸で，これもヒトと一致している。これらの点か らも，導入したヒト免疫グロブリン遺伝子がヒトにおけ ると同様に，マウスのシステムにおいても正常に機能し ていることがわかる.

\section{3. ゼノマウス II を用いたヒトモノクローナル抗体の}

\section{作製}

\section{a） ヒトモノクローナル抗体の作製}

ゼノマウスIIで，ヒトの免疫応答がどの程度再構成さ
1）ゼノマウスへの免疫

2）ゼノマウスリンパ球細胞とミエローマの融合

3）HAT 培地によるハイブリドーマの選択

4）抗原特異的ヒト抗体産生ハイブリドーマのスクリーニング

5）ハイブリドーマのクローニング

6）ハイブリドーマの大量培養

7）ヒトモノクローナル抗体の精製

れているかは，抗体応答を引き出すことのできる抗原の バリエーションと，抗原特異的高親和性モノクローナル 抗体のできやすさで推し量ることができる，ヒトインタ 一ロイキン (IL) - 8, ヒ卜腫䁑壊死因子 (TNF) - $\alpha$ などの 可溶性タンパク質，ヒト上皮成長因子 (EGF) レセプタ 一のような細胞表面抗原を，それぞれゼノマウスIIに免 疫したところ，抗原特異的なヒト $\operatorname{IgG}_{2 \kappa}$ モノクローナル 抗体がそれぞれ 10〜25 種類得られた。抗体の親和性は いずれも $10^{9} \sim 10^{10} / \mathrm{M}$ である. 抗ヒト IL-8 ヒトモノク ローナル抗体も, 抗ヒト TNF- $\alpha$ ヒトモノクローナル 抗体も，それぞれ相当するマウス由来の中和抗体と同様 にレセプターとの結合を阻害した。また，抗ヒト EGF レセプターヒトモノクローナル抗体は, EGFレセプタ 一を発現している A431 細胞に対する EGF の結合を完 全にブロックしている.

ゼノマウスIIを用いたヒトモノクローナル抗体の作製 には，表 1 に示したようなすでに一般化しているハイブ リドーマ技術を用いることができる.ゼノマウス II は, これまで試みたすべてのヒト抗原に対して，強いヒト抗 体産生応答を示した. しかも $10^{10} / \mathrm{M}$ の親和性をもつ抗 体が得られている。

b）ジーンユーセージ

ゼノマウスIIに導入したヒトの遺伝子座の遺伝子断片 が, どのように利用されているかは興味のあるところで ある。ヒト IL-8 およびヒト EGFレセプターに対する ヒトモノクローナル抗体 (8 種類) の可変部遺伝子には, $\mathrm{H}$ 鎖では 5 種類の $\mathrm{V}_{\mathrm{H}}$ 遺伝子断片, 6 種類の $\mathrm{D}$ 遺伝子断 片， 3 種類の $\mathrm{J}_{\mathrm{H}}$ 遺伝子断片が， $x \mathrm{~L}$ 鎖では， 3 種類の $\mathrm{V}_{\kappa}$ 遺伝子断片, 3 種類の $\mathrm{J}_{\kappa}$ 遺伝子断片が使われてお り，これらの組み合わせで抗体遺伝子の可変部が構成さ れている.ゼノマウス II は, これら様々な領域の遺伝子 断片を使うことによって, 多様な抗体を作り出してい る.

\section{c）体細胞突然変異}

$\mathrm{B}$ 細胞は, 膜結合抗体が発現されるようになった後, 体細胞高頻度突然変異によって抗体のもつ多様性をさら に拡大させる。そして抗体の親和性成熟を進める。ゼノ 
マウスIIでも, 体細胞高頻度突然変異による抗体の親和 性成熟が起こっている. 体細胞高頻度突然変異は, 再編 成を終えた $\mathrm{V}$ 領域遺伝子に高頻度にランダムに導入さ れる，発現型の $\mathrm{V}$ 遺伝子では，抗原との結合に関与す る 3 個所の $\mathrm{CDR}$ 領域に集中して, アミノ酸配列が変化 するような塩基対の変異が生じる，一方，アミノ酸配列 が変化しないサイレントな塩基の変異は, フレームワー ク領域全域にわたって分布している.

作製したヒトモノクローナル抗体の $\mathrm{V}_{\mathrm{H}}, \mathrm{V}_{\kappa}$ 遺伝子 を, 相当するヒトの生殖細胞型遺伝子と比較すると, 広 範囲に塩基の置換が起こっていることがわかる，ところ が, 定常部領域ではまったく塩基置換は起こっていな い. 抗体の V 領域における塩基置換のほとんどは, $0 \sim 12$ 個のアミノ酸配列の変化となり, 特に CDR 1 と CDR2 に多くみられる.

\section{4. 光の他のヒト免疫グロブリントランスジェニックマ ウス作製の試み}

最近, 免疫グロブリン遺伝子座のような大きな遺伝子 を，マイクロセルを用いて ES 細胞に導入する方法が報 告された(10).これは, YACを用いる方法に比べて, は るかに大きな遺伝子を導入できるという特徵をもってい る. $\mathrm{H}$ 鎖遺伝子を含むヒトの 14 番染色体, $\lambda \mathrm{L}$ 鎖遺伝 子を含む 22 番染色体, $x \mathrm{~L}$ 鎖遺伝子を含む 2 番染色体 の場合はその断片を，それぞれマイクロセルに入れ， $\mathrm{ES}$ 細胞と融合し，これらの染色体またはその断片をそ のままマウス $\mathrm{ES}$ 細胞に導入し, キメラマウスを作るこ とに成功している。約 1 千万塩基対ほどで，導入したも のの中では比較的小さい 2 番染色体断片の場合は, 生殖 細胞系列を経て子孫まで安定に伝わっているが，残念な がら染色体そのものの生殖細胞系列への移行には成功し ていない，導入した染色体の安定性などの問題があるよ うである。したがって，この方法による実用的な完全ヒ 卜抗体を産生するマウスの作製には，まだ時間がかかる ようである。

\section{5. ファージディスプレー}

M13 ファージは，線状一本鎖 DNA を含み，棒状構 造をしている.この DNAの中に抗体遺伝子を組み込む ことができる，その遺伝子産物は，ファージ粒子を構成 する外殼タンパク質との融合タンパク質として発現さ れ，このファージ粒子表面に抗体として提示される. 発 現された抗体の遺伝子は, ファージ粒子中の DNA にコ ードされているので, ファージをあたかも抗体産生細胞 のように扱える. 抗原抗体反応を利用して抗体をコード
する抗体遺伝子を回収することができる.

$\mathrm{B}$ リンパ細胞に由来する $\mathrm{cDNA}$ を鋳型として, PCR 法により再編成の終わった $\mathrm{V}_{\mathrm{H}}$ と $\mathrm{V}_{\mathrm{L}}$ 遺伝子をそれぞれ 増幅するとともに，これらをランダムに組み合わせてフ アージディスプレーベクターにクローン化することによ り，様々な抗原結合部位を提示するファージライブラリ 一を作製することができる.これは，あらかじめ目的と する抗原で免疫した動物を出発材料として用いると効果 的である，たとえば，過免度したゼノマウスIIから，高 い特異性と親和性をもつ抗体を選択するために, ファー ジディスプレーを使うということもできる.

ファージディスプレーは, 抗体の本来の多様性を利用 して in vitroで多くの抗体を作ることができる.ヒト ゲノムからすべての $\mathrm{V}_{\mathrm{H}}, \mathrm{V}_{\kappa}, \mathrm{V}_{\lambda}$ 遺伝子を単離し, これ らを $\mathrm{D}, \mathrm{J}$ 遺伝子と組み合わせ, 巨大なレパートリーか らなるライブラリーを作る.つまり, 免疫系で起こって いる遺伝子の再編成を行なうわけである。これらの遺伝 子をファージ粒子の DNA に組み込み, 大腸菌に感染さ せる. 抗体の多様性を増加させるために不完全なポリメ ラーゼをもっている大腸菌をホストとして使えば，ファ ージ増殖の際, 不完全なポリメラーゼは正常なポリメラ 一ゼょり高い比率で突然変異を導入することができる. 最終的に, ファージ表面に可変部のみからなる抗体をデ イスプレーする。こうした方法も現在開発されつつあ $ろ^{(11,12)}$.

ゼノマウスIIを用いた方法は, 免疫後, すでに一般化 しているハイブリドーマ法で高親和性のヒト抗体が選択 できることから, 現時点では最も実用的で優れていると いえるであろう。

\section{ヒト抗体の臨床応用}

抗体治療が考えられる疾患分野の中で, 癌は最も大き なターゲットである. 抗体治療研究が始まった初期の 頃, 癌細胞は, その異常性を示すユニークな分子を, 細 胞表面上に提示しているのではないかという期待が大き かった.もしそのような癌特異的な抗原が見つけられた ら，それをターゲットに癌治療が行なえるからである. しかし残念ながら，そのような都合のよい抗原はいまだ に同定されていない. ヒトの癌細胞表面上に存在するほ とんどの抗原は, 正常細胞にもみられている.

ただ，正常細胞と癌細胞では，細胞表面上に存在する 特定の分子の発現量に大きな差がある場合がある. 抗体 による傷害が, 正常細胞では可逆的だが, 癌細胞にとっ ては不可逆的に起こる場合がある.このような差は, 正 


\section{表 2 -主な癌関連抗原}

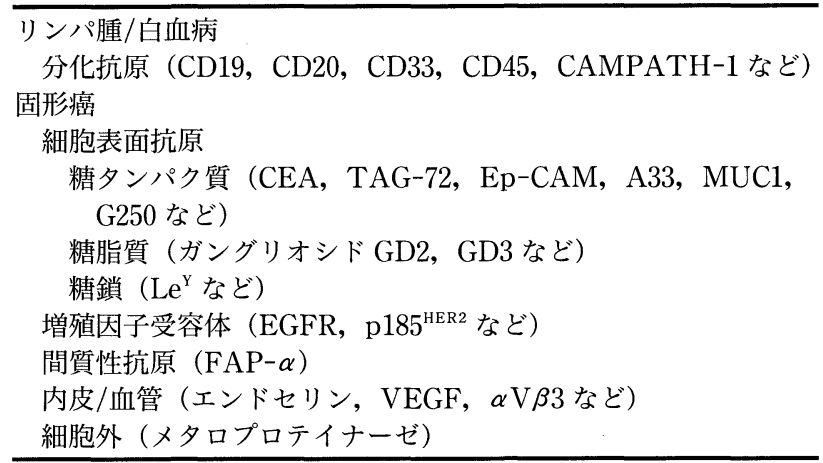

常細胞と癌細胞を識別するために重要である．また，癌 細胞を直接ターゲットにする以外に, 癌の増殖に必要な 細胞や分子をターグットにする場合がある。たとえば， 増殖因子などに対する中和抗体を用いる場合である。ま た，癌細胞間の間質細胞や結合組織をターゲットにする こともできる。こうして数多くの試みがなされてきてい る. 表 2 には，抗体のターゲットとされている代表的な 癌関連抗原を示す ${ }^{(13,14)}$.

抗体を用いた癌細胞の攻め方には，2つの異なった方 法がある，抗体自身が癌細胞を破壊するか，抗体を殺癌 物質の運搬手段として考えるかである．後者に用いられ る殺癌物質としては，ヨード 131 ，イットリウム 99 な どのラジオアイソトープがある。これらは, 癌細胞の DNA を損傷して癌細胞を殺すことができる，また，卜 キシンを使う方法もある，たとえば，トウゴマ種子に含 まれる猛毒性の糖タンパク質のリシンで，タンパク質合 成を阻害する，制癌剂にもしばしばこの目的で用いられ る.また，抗体と結合した酵素で，毒性のないプロドラ ッグを，癌組織でのみ活性化できるようにすることもで きる．炎症反応をひき起こし, 癌組織を破壊できる TNF などの炎症性分子や，アンチセンス DNA の利用 も考えられている。抗体を用いて T 細胞を癌組織に誘 導し, 癌細胞を溶解させるといったストラテジーも試み られている ${ }^{(15,16)}$.

こうした多くの試みも，マウス抗体では免疫原性によ る限界があった。しかし, 最近のドラマチックなヒト抗 体作製技術の開発が，親和性の改善，免疫原性の顕著な 減少などに結びつけば，この分野での急速な発展が大い に期待できる。

$*$

ヒト抗原に対する高い親和性をもつヒト抗体の作製が 可能になった。また，その生産手段としてのゼノマウス IIも実用レベルになっている．この意義は非常に大き
い. マウスモノクローナル抗体またはそれを改良した抗 体であれば避けられない免疫原性の問題やアレルギー応 答を，完全ヒ卜抗体は最小限にすることができるであろ う。そのため，投与した抗体の効果や安全性の増加が期 待できる。慢性で再発しやすいヒトの病気，たとえば炎 症, 自己免疫疾患や癌など，反復投与が必要な病気の治 療に使える抗体として利用できるであろう。

ゼノマウス II は $\mathrm{IgG}_{2}$ タイプのヒト抗体しか作らな い. 適応症によっては異なるエフェクター機能をもつア イソタイプも必要になってくる.ゼノマウスIIが作る七 卜 $\mathrm{IgG}_{2}$ 抗体は，これまでの分子生物学的手法を用いて 他のアイソタイプに容易に変換できる。しかし実用的な 面からは，個々のアイソタイプ抗体を産生できるゼノマ ウスの各バージョンの作製が望まれる。これらは現在開 発が続けられている。

謝辞：本稿執筆の機会を与えていただきました井上國世京都 大学教授に心より御礼申し上げます。

\section{文献}

1）井上國世：化学と生物，34, 240 (1996).

2) C. McNeil : J. Natl. Cancer Inst., 87, 1658 (1995).

3）笹月健彦(監訳)：“免疫生物学”, 南江堂, 1995.

4）野口 浩：医学のあゆみ，167，457 (1993).

5）中谷知右，野口 浩：ファルマシア，33, 24 (1997).

6) M. Neuberger \& M. Brüggemann : Nature, 386, 25 (1997).

7) 岡田 斉, 野田哲生：実験医学, 14, 2710 (1996).

8) M.J. Mendez et al. : Nature Genet., 15, 146 (1997).

9）西 義介：日経サイエンス，6月号，40（1995).

10) K. Tomizuka et al. : Nature Genet., 16, 133 (1997).

11）鶴下直也：ファルマシア，33, 19 (1997).

12）黑沢良和：臨床免疫, 28, 1077 (1996)

13) A.M. Scott \& J. Cebon : Lancet, 349 (suppl II), 19 (1997).

14) A.M. Scott \& S. Welt : Curr. Opin. Immunol., 9, 717 (1997).

15) L.J. Old : Sci. Am., Sep., 136 (1996).

16) A. Furano, A.L. Horenstein \& F. Malavasi : J. Biol. Regulat. Homeost. Agent., 10, 72 (1996). 